Egypt. J. of Appl. Sci., 35 (11) 2020

$172-185$

\title{
PROTECTIVE EFFECT OF DIFFERENT TYPES OF COFFEE EXTRACT ON RATS WITH INDUCED ACUTE LIVER TOXICITY
}

Esraa T. Moawed ; Naeem M. Rabeh and Hany G. EL-Masry

Nutrition and Food Science Department, Faculty of Home Economics, Helwan University, Cairo, Egypt

Key Words: green coffee, Arabic coffee, caffeine, liver toxicity, $\mathrm{CCl}_{4}$, rats.

\begin{abstract}
Coffee (Coffea L.) is the world's beloved drink that is the most regularly consumed caffeine-containing beverage. It contains a complex mixture of chemicals that provide important amounts of chlorogenic acid and caffeine, which associated with many health benefits. The aim of the present study was to investigate the protective effects of conventional, decaffeinated coffee, green coffee and Arabic coffee extract on rats with induced acute liver toxicity. Thirty six adult male albino rats (SpragueDawley strain), weighing about $(180 \pm 10 \mathrm{~g})$ were divided randomly into two main groups as follow: the first group (-ve control= 6 rats) was fed on basal diet. The second group (30 rats) were divided into 5 subgroups from subgroup 1 to subgroup 5. Subgroup 2 (+ve control) fed on basal diet. Subgroups 2 and 5 were given the same dose of extracts $2 \mathrm{ml} / \mathrm{rat}$ of Conventional, Decaffeinated, Arabic and Green coffee, respectively. After 6 weeks, subgroups from (1-5) were injected with one dose of $\mathrm{CCl}_{4}$. At the end of the experimental period (6 weeks), rats were scarified and serum was collected to determine biochemical analysis. The results showed that the administration of $\mathrm{CCl}_{4}$ resulted in significant elevation in serum activities of aspartate aminotransferase (AST) alanine aminotransferase (ALT), alkaline phosphatase (ALP) and total bilirubin whereas serum total proteins albumin and globulin were significantly reduced, along with significant elevation of malondialdehyde level (MDA) and significant depletion in the level of reduced glutathione peroxidase $\left(\mathrm{GP}_{\mathrm{X}}\right)$ compared with negative control. Treatment with extracts of coffee prior to $\mathrm{CCl}_{4}$ produced protective effects and attenuated these biochemical changes. The protective effects of extracts of coffee were more pronounced for the Arabic coffee. It be concluded that coffee beans exhibited hepatoprotective actions along with the restoration of lipid profile in acute liver injury animal models.
\end{abstract}

\section{INTRODUCTION}

Liver is one of the largest organs in human body and the chief site for intense metabolism and excretion. So it has a surprising role in the maintenance, performance and regulating homeostasis of the body. It is 
involved with almost all the biochemical pathways of growth, fight against disease, nutrient supply, energy provision and reproduction (Mroueh et al., 2004). Liver damage is further characterized into hepatocellular predominantly (initial Alanine transferase elevation initial alkaline phosphatase rise) and cholestatic type. Chemicals and drugs such as Carbon tetrachloride $\left(\mathrm{CCl}_{4}\right)$ catabolized radicals induced lipid peroxidation, damage the membranes of liver cells and organelles, causing the swelling and necrosis of hepatocytes and result to the release of cytosolic enzymes in to the blood (Mumoli et al., 2006).

Coffee (Coffea L.) is the world's beloved drink that is the most regularly consumed caffeine-containing beverage. It contains a complex mixture of chemicals that provide important amounts of chlorogenic acid and caffeine, which associated with many health benefits (Higdon and Frei, 2006). Coffee is appreciated for its aroma and flavour, and is a mixture of thousands of different compounds, such as carbohydrates, lipids, alkaloids, vitamins, nitrogenous molecules and phenolic compounds (Spiller, 1998). The roasting process causes a loss of water from the green bean and degradation of many of the compounds including the antioxidant polyphenols; however, there is very little difference in total antioxidants between the different roasts of a bean (Daglia et al., 2000).

Green coffee beans contain $5-14 \%$ of the reported major components, chlorogenic acids (CGAs) are a family of esters formed between certain phenolic acids (trans-cinnamic acids) and quinic acid (Farah and Donangelo, 2006). The roasting process destroys CGAs; therefore, the unroasted beans like green coffee and Arabic coffee are used as the source for this nutritional supplement (Moon and Shibamoto, 2009).

The aim of the present study was to investigate the protective effects of conventional, decaffeinated coffee, green coffee and Arabic coffee extract on rats with $\mathrm{CCl}_{4}$-induced acute liver toxicity, also to evaluate on body weight, feed intake, lipid profile and liver functions that may occur on hepatotoxic rats.

\section{Materials:}

\section{MATERIALS AND METHODS}

Beans of (Conventional coffee and green coffee), and decaffeinated coffee were obtained from Agriculture Research Center, Giza, Egypt. Beans were convert to powder and Arabic coffee were prepared from green coffee with add some flavors with common doses. Carbon tetrachloride and chemical kits were obtained from SigmaAldrich Group., Cairo, Egypt. Casein, cellulose, sucrose, choline chloride, D-L methionine, vitamins and minerals constituents were purchased from El- Gomhoriya Company Cairo, Egypt. Thirty six adult 
male albino rats (Sprague-Dawley strain), weighing about $(180 \pm 10 \mathrm{~g})$ were purchased from the Animal House of the National Research Center, Dokki, Egypt.

\section{Methods:}

1. Preparation of Water Extract of Conventional Coffee, Decaffeinated Coffee, Green Coffee and Arabic Coffee:

Twenty gram of conventional coffee, decaffeinated coffee, green coffee and Arabic coffee powder were submerged in $100 \mathrm{ml}$ of distilled water and were boiled before being given to the rats, then filtered to obtain a liquid extract. A dose of $2 \mathrm{ml} / \mathrm{rat}$ of conventional coffee, decaffeinated coffee, green coffee, caffeine and Arabic coffee extract were given orally respectively by stomach tube.

2. Induction of Acute Liver Toxicity:

Carbon tetrachloride $\left(\mathrm{CCl}_{4}\right)$-induced acute hepatotoxity in rats at the end of the experiment. Intraperitoneal injection of male albino rats with $\mathrm{CCl}_{4} 1 \mathrm{~mL} / \mathrm{kg} / \mathrm{BW}$, (1:1) mixture with paraffin oil according to (karthikeyan and deepa, 2010).

3. Diet Composition and Experimental Animal Design:

The basal diet was formulated according to AIN-93M diet (Reeves et al., 1993). Animals (36 rats) were housed in well conditions in biological studies lab of Faculty of Home Economics. They were left for seven days as adaptation period and they were allowed to feed standard laboratory food and water. After the period of adaptation, animals were divided into two main groups, as follows: - the first main group (6 rats) was fed on basal diet and served as a negative control group (-ve), the second main group (30 rats) were divided as follow:-

Subgroup (1): Rats were fed on basal diet and given only distilled water daily as were kept as positive control group.

Subgroup (2): Rats were given $2 \mathrm{ml} / \mathrm{rat}$ of Conventional Coffee extract.

Subgroup (3): Rats were given $2 \mathrm{ml} /$ rat of Decaffeinated Coffee extract.

Subgroup (4): Rats were given $2 \mathrm{ml} /$ rat of Arabic Coffee extract.

Subgroup (5): Rats were given $2 \mathrm{ml} /$ rat of Green Coffee extract.

After 6 weeks, subgroups from (1-5) were injected with one dose of $\mathrm{CCl}_{4}$ (Karthikeyan and Deepa, 2010).

\section{Biological Evaluation:}

Feed intake will be recorded daily and animals will be weighed at the beginning and twice a week throughout the experimental period. 
Body weight gain $\%$ and feed efficiency ratio will be calculated at the end of the experiment according to the method of Chapman et al., (1959).

\section{Blood Collection And Serum Separation:}

At the end of the experimental period (6 weeks), rats were fasted overnight before scarifying and blood samples were collected from each rat and were centrifuged at $3000 \mathrm{rpm}$ for $15 \mathrm{~min}$ to obtain the serum for biochemical analysis.

\section{Biochemical Analysis of Serum:}

Aspartate aminotransaminase (AST) and Alanine aminotransaminases (ALT) were determined according to the method described by Young, (2001), and Alkaline phosphates (ALP) was determined according to Roy, (1970). Total bilirubin, Malondialdehyde (MDA) and Glutathione peroxidase (GPx) were determined according to Young, (2001); Draper and Hadley, (1990) and Hissin and Hilf, (1970), respectively. Serum total cholesterol (TC), triglyceride (TG), high density lipoprotein cholesterol (HDL-C) were determined according to Richmond, (1973); Wahlefeld, (1974) and Albers et al., (1983), respectively. Regarding to serum low density lipoprotein cholesterol (LDL-C) and very low density lipoprotein cholesterol (VLDL-C) were calculated according to Fridewald $\boldsymbol{e t}$ al., (1972). Total protein, albumin and globulin were determined in the serum according to method describe by Burtis and Ashwood, (1999); Young, (2001) and Goldenberg and Drewes, (1971), respectively. The biochemical determinations were conducted at the National Research Center, Giza, Egypt.

\section{Statistical Analysis:}

Results were expressed as the mean standard error \pm SE. Data were statistically analyzed for variance "ANOVA" test at $\mathrm{P} \leq(0.05)$ using SPSS statistical software, version 20 was used for these calculations (Armitage and Berry, 1987).

\section{RESULTS AND DISCUSSION}

Results recorded in Table 1 showed the effect of diet supplemented with extracts of Conventional, Decaffeinated, Arabic and Green Coffee on FI, BWG \% and FER of Hepatotoxic Rats. Feed intake was decreased in positive control group compared to negative control group, while groups treated with extracts of Conventional, Decaffeinated, Arabic and Green Coffee were reduced in feed intake compared to negative control group. There were significantly decreased $(\mathrm{P}<0.05)$ in $\mathrm{BWG}$ and FER for the positive control group compared to the negative control group, it was also showed that all treatment groups with extracts of Conventional, Decaffeinated, Arabic and Green Coffee significantly increased $(\mathrm{P}<0.05)$ in BWG and FER compared with positive control group expect BWG in 
group treated with Conventional Coffee non significantly compared to positive control group.

Table (1): Effect of Conventional, Decaffeinated, Arabic and Green Coffee Extract on Feed Intake (FI), Body Weight Gain \% (BWG \%) and Feed Efficiency Ratio (FER) in Rats with $\mathrm{CCl}_{4}$-Induced Acute Liver Toxicity

\begin{tabular}{|c|c|c|c|}
\hline $\begin{array}{l}\text { Parameters } \\
\text { Groups }\end{array}$ & FI (g/d) & BWG\% & FER \\
\hline Negative Control & 15.00 & $34.05 \pm 0.05^{\mathrm{a}}$ & $0.136 \pm 0.004^{\mathrm{a}}$ \\
\hline Positive Control & 14.00 & $17.16 \pm 0.84^{\mathrm{e}}$ & $0.070 \pm 0.001^{\mathrm{c}}$ \\
\hline Conventional Coffee & 13.50 & $23.53 \pm 0.83^{\mathrm{cd}}$ & $0.122 \pm 0.002^{b}$ \\
\hline Decaffeinated Coffee & 12.00 & $21.53 \pm 0.53^{\mathrm{de}}$ & $0.124 \pm 0.024^{b}$ \\
\hline Arabic Coffee & 13.00 & $31.94 \pm 0.78^{a b}$ & $0.138 \pm 0.037^{a}$ \\
\hline Green Coffee & 14.00 & $27.51 \pm 0.83^{b c}$ & $0.130 \pm 0.001^{a b}$ \\
\hline
\end{tabular}

*Mean values are expressed as means $\pm \mathrm{SE}$.

*Mean values at the same column with the same superscript letters are not statistically significant at $\mathbf{P}<\mathbf{0 . 0 5}$.

Results in Table 1 indicated that $\mathrm{CCl}_{4}$ administration significantly lowered FI, BWG and FER compared to negative control group, these results were in the same line with Shaker et al., (2010) and Wang et al., (2018). Mohmoud et al., (2013) found that the feeding on different doses of Arabic coffee for 30 days lowered body weight in rats fed on basal diet. The possible mechanism by which coffee prevented higher body weight gain in the present study could be by increasing lipolysis via catecholamines (Kobayashi-Hattori et al., 2005 and Lopez-Garcia et al., 2006). Caffeine might also have caused body weight loss by increasing physical activity. It is known that green coffee effects the body weight, green coffee extract has a hypotensive effect in mice, decreases visceral fat and body weight (Jeszka-Skowron et al. 2016).

As seen in Table 2, serum concentrations of aspartate aminotransferase (AST), alanine aminotransferase (ALT), alkaline phosphatase (ALP) and total bilirubin were significantly $(\mathrm{P}<0.05)$ elevated by $\mathrm{CCl}_{4}$ administration (positive control group) compared with negative control group. It was observed significant $(\mathrm{P}<0.05)$ reduce in serum AST, ALT, ALP and total bilirubin levels for all groups treated with extracts of Conventional, Decaffeinated, Arabic and Green Coffee compared to positive control group, group treated with Arabic Coffee was close to the negative control group.

Mahmoud et al., (2013) evaluated the effect of consumption of different levels of Arabic coffee on blood parameters concentration. Blood samples were collected and used for determination of ALT, and AST. These parameters were found to be significantly lower in group treated with coffee than control group. These results are in accordance to other studies in which coffee consumption displayed reduction of liver 
functioning enzymes such as, AST, ALT and ALP as prevention from cirrhosis and fibrosis (Sadiq et al., 2019).

Table (2): Effect of Conventional, Decaffeinated, Arabic and Green Coffee Extract on Serum AST, ALT, ALP and Total Bilirubin in Rats with $\mathbf{C C l}_{4}$-Induced Acute Liver Toxicity

\begin{tabular}{|c|c|c|c|c|}
\hline \multirow{2}{*}{ Groups } & AST & ALT & ALP & \multirow{2}{*}{$\begin{array}{c}\begin{array}{c}\text { Total } \\
\text { Bilirubin }\end{array} \\
\text { mg/dL } \\
\end{array}$} \\
\hline & \multicolumn{3}{|c|}{$\mathbf{U} / \mathbf{L}$} & \\
\hline Negative Control & $91.96 \pm 0.83^{f}$ & $29.64 \pm 0.54^{d}$ & $88.84 \pm 0.48^{\mathrm{e}}$ & $0.39 \pm 0.014^{d}$ \\
\hline Positive Control & $140.79 \pm 0.42^{\mathrm{a}}$ & 48.01 $\pm 0.52^{\mathrm{a}}$ & $150.26 \pm 0.32^{\mathrm{a}}$ & $0.91 \pm 0.010^{\mathrm{a}}$ \\
\hline Conventional coffee & $129.65 \pm 0.30^{b}$ & $34.62 \pm 0.98^{c}$ & $108.97 \pm 0.58^{b c}$ & $0.58 \pm 0.016^{\mathrm{c}}$ \\
\hline Decaffeinated coffee & $124.33 \pm 0.89^{c}$ & $38.45 \pm 0.90^{b}$ & $114.35 \pm 0.98^{b}$ & $0.69 \pm 0.017^{b}$ \\
\hline Arabic coffee & $97.09 \pm 0.98^{\mathrm{e}}$ & $30.42 \pm 0.90^{d}$ & $98.09 \pm 0.99^{d}$ & $0.40 \pm 0.006^{d}$ \\
\hline Green coffee & $101.36 \pm 0.71^{d}$ & $32.44 \pm 0.44^{\mathrm{cd}}$ & $103.69 \pm 0.95^{\text {cd }}$ & $0.43 \pm 0.007^{d}$ \\
\hline
\end{tabular}

*Mean values are expressed as means $\pm \mathrm{SE}$.

*Mean values at the same column with the same superscript letters are not statistically significant at $\mathrm{P}<0.05$.

Green coffee bean extract contains chlorogenic acid (CGA) as the principal constituent, and most of the health benefits of decaffeinated coffee and its by-product have been attributed to chlorogenic acid (Stohs and Badmaev, 2016). The effects induced by repeated $\mathrm{CCl}_{4}$ administration were attenuated by conventional and decaffeinated, arabica and green coffee intake. These findings confirm the beneficial effects of coffee and against liver injury induced by other hepatotoxicants (Ozercan et al., 2006; Lee et al., 2007; Shi et al., 2010 and Moreno et al., 2011). However, a suitable evaluation of the protective efficacy of coffee beverages and caffeine against different stages of carcinogenesis might be better warranted in other models of rat liver carcinogenesis (Okano et al., 2008 and Silva- Oliveira et al., 2010).

Results in Table 3 showed a significant decrease $(\mathrm{P}<0.05)$ in serum glutathione peroxidase $\left(\mathrm{GP}_{\mathrm{X}}\right)$ activity of the positive control group compared with the negative control group. It was clear that, there was significant $(\mathrm{P}<0.05)$ increase in serum $\mathrm{GP}_{\mathrm{X}}$ activity for all treated groups with Coffee compared to the positive control group. Concerning to serum malondialdehyide (MDA) level, results showed that serum MDA level was significantly increased $(\mathrm{P}<0.05)$ in the positive control group compared with the negative control group whereas all treated groups with Coffee significantly decreased $(\mathrm{P}<0.05)$ compared to the positive control group. It was also observed that rats were fed on Arabic coffee rextract 
considered the best group for enhancing the serum $\mathrm{GP}_{\mathrm{X}}$ and reducing serum MDA levels.

Table (3): Effect of Conventional, Decaffeinated, Arabic and Green Coffee Extract on Serum GP G $_{X}$ and MDA in Rats with $\mathrm{CCl}_{4}$-Induced Acute Liver Toxicity

\begin{tabular}{|c|c|c|}
\hline Proups & $\begin{array}{l}\mathbf{G P}_{\mathbf{X}} \\
(\mathbf{U} / \mathbf{m g})\end{array}$ & $\begin{array}{c}\text { MDA } \\
(\mu \mathrm{mol} / \mathrm{dL})\end{array}$ \\
\hline Negative Control & $64.03 \pm 0.61^{\mathrm{a}}$ & $9.80 \pm 0.19^{\mathrm{e}}$ \\
\hline Positive Control & $29.10 \pm 0.98^{\mathrm{e}}$ & $22.11 \pm 0.51^{\mathrm{a}}$ \\
\hline Conventional coffee & $46.71 \pm 0.93^{\mathrm{c}}$ & $15.02 \pm 0.40^{\text {bc }}$ \\
\hline Decaffeinated coffee & $40.72 \pm 0.29^{d}$ & $17.02 \pm 0.34^{b}$ \\
\hline Arabic coffee & $63.62 \pm 0.91^{\mathrm{a}}$ & $12.74 \pm 0.41^{d}$ \\
\hline Green coffee & $54.62 \pm 0.72^{b}$ & $13.28 \pm 0.73^{\text {cd }}$ \\
\hline
\end{tabular}

*Mean values are expressed as means $\pm \mathrm{SE}$.

*Mean values at the same column with the same superscript letters are not statistically significant at $\mathbf{P}<\mathbf{0 . 0 5}$.

Demirtaş et al., (2012) reported that caffeine doses decreased lipid peroxidation (MDA) in liver. Antioxidant enzyme activities in the rat liver, like GPx, showed a statistically significant increase with caffeine intake. Chlorogenic acid, a phenolic compound found in green coffee, has antioxidant activity and has the ability to trap superoxide anions or hydroxyl radicals (Castro et al., 2018). Cholorogenic acids are strong reactive oxygen species (ROS) scavengers. ROS are produced physiologically during various cellular processes such as aerobic metabolism and should be harmful when the amount is high. Even though ROS are known to be harmful, in order to sustain cellular homeostasis through redox cell signalling, they must be at a certain level (Priftis et al., 2018).

Data revealed in Table 4 that serum TC, TG, LDL-C and VLDL-C were significantly $(\mathrm{P}<0.05)$ increased in the positive control group compared with the negative control group. Results also illustrated that all groups that were treated with coffee decreased significantly $(\mathrm{P}<$ 0.05) in serum TC, TG and VLDL-C levels compared to the positive control group. Regarding serum HDL-C level, results showed a significant $(\mathrm{P}<0.05)$ decrease in serum HDL-C level of the positive control group compared to the negative control group. There was a significant change in serum HDL-C level for all treated groups with coffee compared to negative control group. The highest improvement for 
lipid profile was observed at the groups treated with by the extracts of Arabic and Green coffee.

Table (4): Effect of Conventional, Decaffeinated, Arabic and Green Coffee Extract on Serum TG, TC, HDL-C, LDL-C and VLDL-C in Rats with $\mathrm{CCl}_{4}$-Induced Acute Liver Toxicity

\begin{tabular}{|c|c|c|c|c|c|}
\hline Parameters & TG & TC & HDL & LDL & VLDL \\
\hline Groups & \multicolumn{5}{|c|}{$\mathrm{mg} / \mathrm{dl}$} \\
\hline Negative Control & $45.03 \pm 0.38^{f}$ & $89.19 \pm 0.38^{d}$ & $44.37 \pm 0.63^{a}$ & $35.46 \pm 0.48^{d}$ & $9.00 \pm 0.76^{f}$ \\
\hline Positive Control & $112.62 \pm 0.83^{\mathrm{a}}$ & $146.64 \pm 0.65^{a}$ & $25.03 \pm 0.24^{f}$ & $99.09 \pm 0.57^{\mathrm{a}}$ & $22.52 \pm 0.16^{\mathrm{a}}$ \\
\hline Conventional coffee & $98.08 \pm 0.98^{c}$ & $124.47 \pm 0.98^{b}$ & $31.85 \pm 0.72^{d}$ & $73.00 \pm 0.89^{b}$ & $19.61 \pm 0.43^{\mathrm{c}}$ \\
\hline Decaffeinated coffee & $103.00 \pm 0.92^{b}$ & $130.47 \pm 0.36^{b}$ & $27.68 \pm 0.59^{\mathrm{e}}$ & $82.02 \pm 0.65^{b}$ & $20.75 \pm 0.18^{b}$ \\
\hline Arabic coffee & $67.38 \pm 0.73^{\mathrm{e}}$ & $93.83 \pm 0.99^{d}$ & $36.04 \pm 0.43^{c}$ & $44.31 \pm 0.89^{c}$ & $13.70 \pm 0.14^{\mathrm{e}}$ \\
\hline Green coffee & $73.53 \pm 0.60^{d}$ & $105.43 \pm 0.97^{c}$ & $39.44 \pm 0.35^{b}$ & $51.28 \pm 0.97^{\mathrm{c}}$ & $14.70 \pm 0.12^{d}$ \\
\hline
\end{tabular}

*Mean values are expressed as means $\pm \mathrm{SE}$.

*Mean values at the same column with the same superscript letters are not statistically significant at $\mathbf{P}<0.05$.

Liver is the major site for the synthesis and metabolism of cholesterol (Yang et al., 2011). Distinct alterations in lipid metabolism have been reported in $\mathrm{CCl}_{4}$ induced hepatotoxicity in rats (Singhal and Gupta, 2012). The present results expressed the significant increasing in levels of serum TG, TC, LDL-C and VLDL-C, while decreasing in HDL$\mathrm{C}$ level in $\mathrm{CCl}_{4}$ inducted rats. Treatment of coffee also attenuated these changes of lipid profile of rats treated previously with $\mathrm{CCl}_{4}$. These results were in the same line with Sadiq et al., (2019) who reported that Arabica coffee decreased the levels of TG, TC and LDL in co-treated group, while an elevation in HDL levels is also there. This could also be attributed to the various bioactive molecules identified, along with various fat-soluble compounds (Lee, 2000). It is suggested that, both, the type and mode of coffee preparation strongly affect the lipid profile modulation (Corrêa et al., 2013). The bioactive molecules, cafestol and kahewol are found in considerable amounts in unfiltered boiled coffee, that enhance TG, TC and LDL (Heckers et al., 1994; Weusten-Van der Wouw et al., 1994; Urgert et al., 1997).

Green coffee directly affects all the parameters of the lipid profile (Shimoda et al., 2006). The phytoconstituent of green coffee beans was reported to significantly improve the levels of HDL and VLDL (Meng et al., 2013). Additionally, green coffee was reported to decrease the levels of cholesterol, triglyceride, and LDL (Yukawa $\boldsymbol{e t}$ al., 2004). 
In Table 5, $\mathrm{CCl}_{4}$ treatment significantly $(\mathrm{p}<0.05)$ reduced serum total proteins, albumin and globulin as compared to negative control. Groups treated with extracts of Conventional, Decaffeinated, Arabic and Green Coffee have a significant increase compared to positive control group. The best improvement of serum total proteins, albumin and globulin was observed in the group treated with Arabic coffee.

Results in Table 5 were in agreement with Hussein et al., (2020), who reported that the treatment with green coffee significantly increased levels of total protein, albumin and globulin compared to positive control group. On the other hand, Birkner et al., (2006) showed that the level of total protein increased after treatment with caffeine.

Table (5): Effect of Conventional, Decaffeinated, Arabic and Green Coffee Extract on Serum Total Protein, Albumin and Globulin in Rats with $\mathrm{CCl}_{4}$-Induced Acute Liver Toxicity

\begin{tabular}{|c|c|c|c|}
\hline \multirow{2}{*}{ Groups } & Total Protein & Albumin & Globulin \\
\hline & \multicolumn{3}{|c|}{ g/dL } \\
\hline Negative Control & $5.02 \pm 0.06^{\mathrm{a}}$ & $3.65 \pm 0.13^{a}$ & $2.18 \pm 0.88^{a}$ \\
\hline Positive Control & $2.43 \pm 0.15^{\mathrm{c}}$ & $0.98 \pm 0.13^{d}$ & $1.17 \pm 0.27^{d}$ \\
\hline Conventional coffee & $2.63 \pm 0.13^{c}$ & $2.29 \pm 0.11^{\mathrm{c}}$ & $1.24 \pm 0.24^{\mathrm{d}}$ \\
\hline Decaffeinated coffee & $3.76 \pm 0.09^{b}$ & $1.97 \pm 0.58^{c}$ & $1.40 \pm 0.10^{c d}$ \\
\hline Arabic coffee & $4.75 \pm 0.11^{\mathrm{a}}$ & $2.89 \pm 0.40^{b}$ & $1.99 \pm 0.11^{\mathrm{ab}}$ \\
\hline Green coffee & $4.00 \pm 0.10^{b}$ & $3.31 \pm 0.97^{\mathrm{a}}$ & $1.73 \pm 0.14^{b c}$ \\
\hline
\end{tabular}

*Mean values are expressed as means $\pm \mathrm{SE}$.

*Mean values at the same column with the same superscript letters are not statistically significant at $\mathbf{P}<0.05$.

\section{CONCLUSION:}

Coffee is beneficial for health in general and particularly for patients with liver disease. Consumption of coffee protects against progression of almost all forms of liver disease. Usual mechanisms involved are prevention of fibrosis, carcinogenesis, and antioxidant effect. The incidence of advanced fibrosis and cirrhosis is lower among coffee drinkers. The risk of hepatocellular carcinoma also is lower in coffee drinkers compared to the non-coffee consuming population. However, in view of retrospective nature of data, more interventional trials are required before coffee finds its way in the regular prescription in liver disease patients.

\section{REFERENCES}

Albers, N. ; V. Benderson and G. Warnick (1983): Enzaymatic determination of high density lipoprotein cholesterol, Selected Methods. Clin. Chem., 10:91-99. 
Armitage, G. and W. Berry (1987): Statistical methods 7th Ed. Ames., Iowa state university. Press.,Pp: 39-63.

Birkner, E. ; E. Grucka-Mamczar ; K. Zwirska-Korczala ; J. ZalejskaFiolka ; B. Stawiarska-Pieta ; S. Kasperczyk and A. Kasperczyk (2006): Influence of sodium fluoride and caffeine on the kidney function and free-radical processes in that organ in adult rats. Biological Trace Element Research, 109: 35-47.

Burtis, C. and E. Ashwood (1999): Tietz textbook of clinical chemistry. 3rd ed. Philadelphia:W.B. Saunders, 1999: 1840, 1841, 1844, 1845; 1799; 1834-5 Textbook of Clinical Chemistry, 3rd ed AACC.

Castro, A. ; F. Oda ; M. Almeida-Cincotto ; M. Davan ${ }_{s}$ co ; B. Chiari ; Andreo ; R. Cicarelli ; R. Peccinini ; G. Zocolo ; P. Ribeiro and M. Correa (2018): Green coffee seed residue: A sustainable source of antioxidant compounds. Food Chemistry, 246: 48-57.

Chapman, D.; R. Gastilla and J. Campbell (1959): Evaluation of protein in foods: 1- A Method for the determination of protein efficiency ratio. Can. J. Biochem. Phys; 37:679- 86.

Corrêa, T. ; M. Rogero ; B.Mioto ; D.Tarasoutchi ; V.Tuda ; L. César and E. Torres (2013): Paper-filtered coffee increases cholesterol and inflammation biomarkers independent of roasting degree: A clinical trial. Nutrition., 29: 977-981.

Daglia, M.; A. Papetti; C.Gregotti; F. Berte and G. Gazzani (2000): In vitro antioxidant and ex vivo protective activities of green and roasted coffee. J. Agric. Food Chem., 48: 1449-1454.

Demirtaş, C. ; E. Ofluoğlu ; A. Hussein and H. Paşaoğlu (2012): Effects of caffeine on oxidant-antioxidant mechanisms in the rat liver. Gazi Med J., 23: 13-8.

Draper, H. and Hadley, M. (1990): Malondialdehyde determination as index of lipid peroxidation. Methods Enzymol. 186: 421-31.

Farah, A. and C. Donangelo (2006): Phenolic compounds in coffee. Brazil J Plant Physiol 18:23-36.

Fridewald, W. ; R. Leve and D. Fredrickson (1972): Estimation of the concentration of low density lipoprotein separated by three different methods. Clin.Chem., 18: 499-502.

Goldenberg, H. and P. Drewes (1971): Direct Photometric Determination of Globulin in Serum. Clinical Chemistery, 17 (5): $358-362 .$. 
Heckers, H. ; U. Göbel and U. Kleppel (1994): End of the coffee mystery: diterpene alcohols raise serum low-density lipoprotein cholesterol and triglyceride levels. Journal of Internal Medicine., 235: 192-193.

Higdon, J. and B. Frei (2006): Coffee and health: a review of recent human research. Critical reviews in food science and nutrition 46: 101-123.

Hissin, P. and R. Hilf (1970): A fluorometric method for determination of oxidized and reduced glutathione in tissues. Anal Biochem., 74(1): 214-26.

Hussein, M. ; M. Samy ; A. Arisha ; I. Saadeldin and G. Alshammari (2020): Anti-obesity effects of individual or combination treatment with Spirulina platensis and green coffee bean aqueous extracts in high-fat diet-induced obese rats. All Life, 13(1): 328-338.

Jeszka-Skowron, M. ; A. Sentkowska ; K. Pyrzyńska and M. Paz De Peña (2016): Chlorogenic acids, caffeine content and antioxidant properties of green coffee extracts: influence of green coffee bean preparation. European Food Research and Technology, 242: 1403-1409.

Karthikeyan, M. and K. Deepa (2010): Hepatoprotective effect of premnacorymbosa (Burm f.) Rottl.\&willd leaves extract on CCl4 induced hepatic damage in Wistar albino rat . Asian Pac. J .trop. Med., 3(1):17- 20.

Kobayashi-Hattori, K. ; A. Mogi ; Y. Matsumoto and T. Takita (2005): Effect of caffeiene on the body fat and lipid metabolism of rats fed on a high-fat diet. Bioscience Biotechnology and Biochemistry, 69(11): 2219-2223.

Lee, C. (2000): Antioxidant ability of caffeine and its metabolites based on the study of oxygen radical absorbing capacity and inhibition of LDL peroxidation. Clinica Chimica Acta., 295: 141-154.

Lee, K. ; J. Choi and H. Jeong (2007): Hepatoprotective and antioxidant effects of the coffee diterpenes kahweol and cafestol on carbon tetrachloride-induced liver damage in mice. Food Chem Toxicol, 45: 2118-2125.

Lopez-Garcia, E. ; M. van Dam and S. Rajpathak (2006): Changes in caffeine intake and long-term weight change in men and women. Am J Clin Nutr., 83: 674-680. 
Mahmoud, O. ; N. Al-Qahiz and M. Ismail (2013): Different Doses of Arabic Coffee Improve Serum Lipid Profile, Uric Acid and Liver Enzymes of Experimental Rats. Food and Public Health, 3(4): 228-233.

Meng, S. ; J. Cao ; Q. Feng ; J. Peng and Y. Hu (2013): Roles of chlorogenic acid on regulating glucose and lipids metabolism: A review. Evid Based Complement Alternat Med.

Moon, J. and T. Shibamoto (2009): Role of roasting conditions in the profile of volatile flavor chemicals formed from coffee beans. $J$ Agric Food Chem., 57:5823-5831.

Moreno, M. ; E. Chávez ; L. Aldaba-Muruato ; J. Segovia ; P. Vergara and V. Tsutsumi (2011): Coffee prevents $\mathrm{CCl}_{4}$ induced liver cirrhosis in the rat. Hepatol Int., 5:857-863.

Mroueh, M.; Y. Saab and R. Rizkallah (2004): Hepatoprotective activity of Centauriumerythraea on acetaminophen-induced hepatotoxicity in rats. Phytother., 18:431-3.

Mumoli, N.; M. Cei and A. Cosimi (2006): Drug-related hepatotoxicity. N. Engl. J. Med.,354 (20): 2191-3.

Okano, J. ; T. Nagahara,; K. Matsumoto and Y. Murawaki (2008): Caffeine inhibits the proliferation of liver cancer cells and activates the MEK/ERK/EGFR signalling pathway. Basic Clin Pharmacol Toxicol., 102: 543-551.

Ozercan, I. ; A. Dagli ; B. Ustundag ; M .Ozercan ; I. Bahcecioglu and Celik, H. (2006): Does instant coffee prevent acute liver injury induced by carbon tetrachloride $\left(\mathrm{CCl}_{4}\right)$ ?. Hepatol Res., 35: $163-168$.

Priftis, A. ; A. Mitsiou ; M. Halabalaki and G. Ntasi (2018): Roasting has a distinct effect on the antimutagenic activity of coffee varieties. Mutation Research/Genetic Toxicology and Environmental Mutagenesis, 829-830.

Reeves, P.; F. Nielsen and G. Fahey (1993): AIN-93 purified diets for laboratory rodents: Final report of the American Institute of Nutrition and hoc writing committee on the reformulation of the AIN- 76A rodent diet. J. Nutr., 123(11):1939-1951.

Richmond, N. (1973): Colorimetric determination of total cholesterol and high density lipoprotein cholesterol (HDL-c). Clin. Chem., 19: $1350-1356$.

Roy, S.E. (1970): colorimetric method of serum alkaline phosphatase. Journal of Clinical Chemistry, 16:431-432. 
Sadiq, F. ; I. Channa ; M. Safdar ; Y. Junejo ; R. Khailany ; M. Ahktar ; M. Saeed ; N. Badar ; M. Badar ; M. Ozaslan and M. Gondal (2019): Hepatoprotective effects of arabica coffee beans in paracetamol induced hepatotoxic animal models. Int. J. Biosci., 15(1): 340-351.

Shaker, E. ; H. Mahmoud and S. Mnaa (2010): Silymarin the antioxidant component and Silybum marianum prevents liver damage. Food Chem. Toxicol., 48 (3): 803-806.

Shi, H. ; L. Dong ; Y. Zhang ; Y. Bai ; J. Zhao and L. Zhang (2010): Protective effect of a coffee preparation (Nescafe pure) against carbon tetrachloride-induced liver fibrosis in rats. Clin Nutr., 29: 399-405.

Shimoda, H. ; E. Seki and M.Aitani (2006): Inhibitory effect of green coffee bean extract on fat accumulation and bodyweight gain in mice. BMC Complement Altern Med., 6:19.

Silva-Oliveira, E. ; P. Fernandes and T. Moraes-Santos (2010): Effect of coffee on chemical hepatocarcinogenesis in rats. Nutr Cancer, 62: 336-342.

Singhal, G. and D. Gupta (2012): Hepatoprotective and antioxidant activity of methanolic extract of flowers of Nerium oleander against CCl4-induced liver injury in rats. Asian Pacific Journal of Tropical Medicine, 5(9): 677-685.

Spiller, M.A. (1998): The chemical components of coffee. In Caffeine, Spiller GA (ed.). Boca Raton: CRC Press; 97-161.

Stohs, S. and V. Badmaev (2016): A review of natural stimulant and nonstimulant thermogenic agents. Phytother Res., 30(5): 732 -40.

Urgert, R. ; N. Essed ; G. Van der Weg ; T. Kosmeijer-Schuil and M. Katan (1997): Separate effects of the coffee diterpenes cafestol and kahweol on serum lipids and liver aminotransferases. The American Journal of Clinical Nutrition., 65: 519-524.

Wahlefeld, A. (1974): Methods of Enzymatic Analysis. Academic Press, Chapter, 5: 1831-1835.

Wang, R. ; J. Wang ; F. Song ; S. Li and Y. Yuan (2018): Tanshinol ameliorates $\mathrm{CCl}_{4}$-induced liver fibrosis in rats through the regulation of $\mathrm{Nrf} 2 / \mathrm{HO}-1$ and $\mathrm{NF}-\kappa \mathrm{B} / \mathrm{I} \kappa \mathrm{B} \alpha$ signaling pathway. Drug Design, Development and Therapy, 12: 1281-1292.

Weusten-Van der Wouw, M. ; M. Katan ; R. Viani ; A. Huggett ; R. Liardon ; P. Lund-Larsen ; D. Thelle ; I. Ahola and A. Aro (1994): Identity of the cholesterol-raising factor from boiled 
coffee and its effects on liver function enzymes. Journal of Lipid Research., 35: 721-733.

Yang, L. ; C. Wang ; Z. Ye and T. Li (2011): Hepatoprotective effects of polyprenols from Ginkgo biloba L. leaves on $\mathrm{CCl}_{4}$-induced hepatotoxicity in rats. Fitoterapia, 82(6): 834-840.

Young, D. (2001): Effect of disease on clinical lab Tests, $4^{\text {th }}$ ed. AACC press.

Yukawa, G. ; M. Mune ; H. Otani ; Y. Tone ; X. Liang ; H. Iwahashi and W. Sakamoto (2004): Effects of coffee consumption on oxidative susceptibility of low-density lipoproteins and serum lipid levels in humans. Biochemistry (Mosc)., 69(1):70-74.

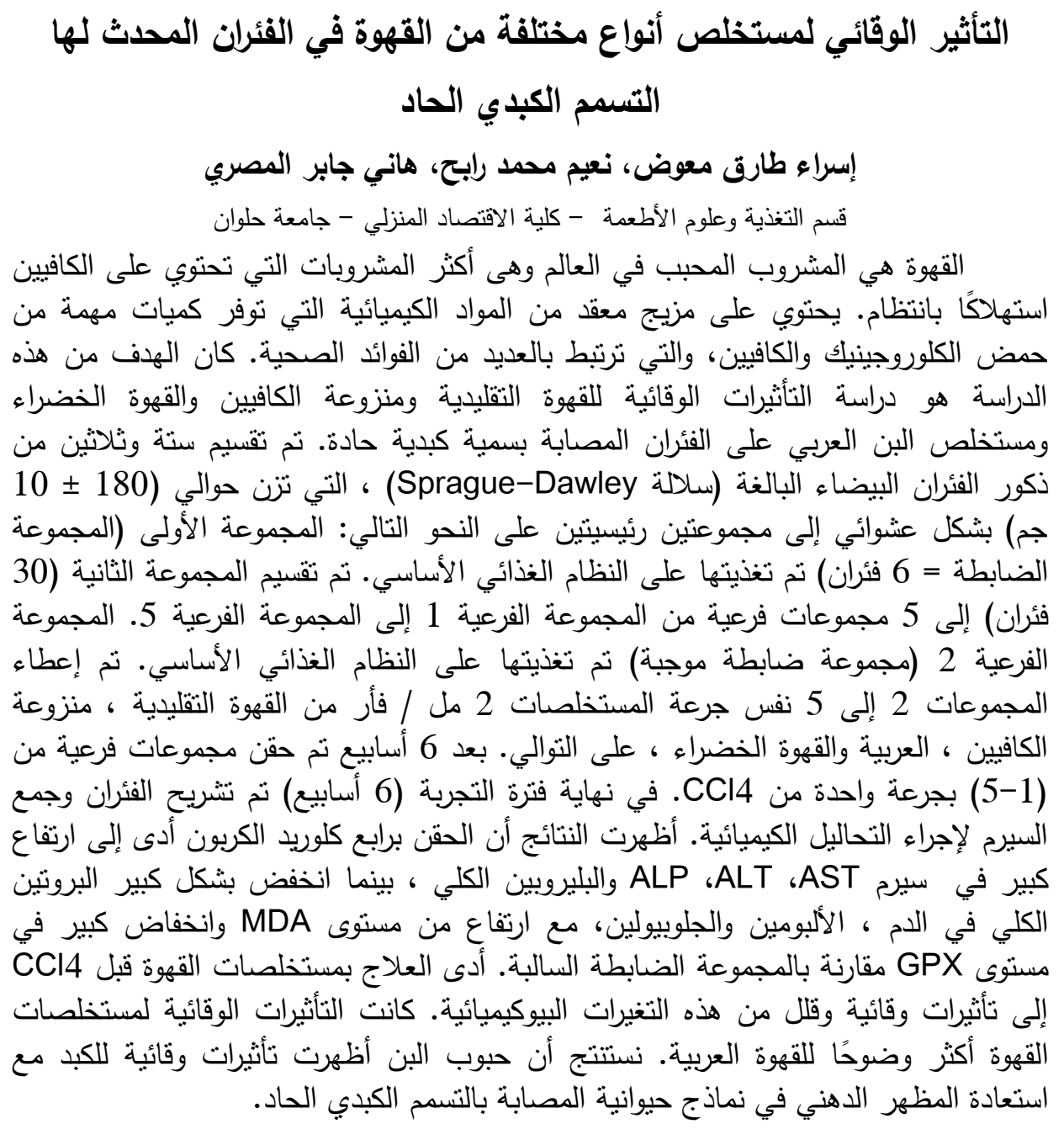

